\title{
The anti-addictive drug ibogaine modulates voltage-gated ion channels and may trigger cardiac arrhythmias
}

\author{
Michael Kovar, Xaver Koenig, Ágnes Mike, René Cervenka, Péter Lukács, Hannes Todt, Walter Sandtner, \\ Karlheinz Hilber
}

From 17th Scientific Symposium of the Austrian Pharmacological Society (APHAR). Joint meeting with the Hungarian Society of Experimental and Clinical Pharmacology (MFT)

Innsbruck, Austria. 29-30 September 2011

\section{Background}

Ibogaine is an alkaloid derived from the African shrub Tabernanthe iboga. Psychoactive properties of ibogaine have been known for decades, but more recently the drug has received much attention because of its promising "anti-addictive" actions. Thus, ibogaine and its derivatives are being studied as potential treatment for opioid and stimulant abuse, as well as for alcoholism and smoking. Because ibogaine has a complex pharmacology and is known to interact with numerous different cellular targets, its potential to generate adverse effects is significant. Besides the expected neurotoxic actions, ibogaine may e.g. also affect the heart. Thus, several cases of sudden death after ibogaine use were reported, which have been hypothesised to be related to cardiac arrhythmias. In accordance, a severely prolonged QT interval of the electrocardiogram and ventricular tachyarrhythmias were observed in a woman after she had taken ibogaine.

\section{Methods}

To study possible mechanisms by which ibogaine may trigger cardiac arrhythmias, we explored ibogaine's effects on the function of cardiac voltage-gated ion channels, by using the whole-cell patch-clamp technique. In addition, we also tested the ibogaine derivative 18 -methoxycoronaridine (18-MC), which is considered less toxic.

\footnotetext{
* Correspondence: karlheinz.hilber@meduniwien.ac.at

Department of Neurophysiology and Neuropharmacology, Center for Physiology and Pharmacology, Medical University of Vienna, 1090 Vienna, Austria
}

\section{Results}

We found that currents through human ERG (hERG) potassium channels, heterologously expressed in tsA201 cells, were inhibited by ibogaine in low micromolar concentrations $\left(\mathrm{IC}_{50}: 3 \mu \mathrm{M}\right)$. In addition, ibogaine significantly altered the $\mathrm{hERG}$ channel gating properties. The $\mathrm{IC}_{50}$ of hERG current inhibition by $18-\mathrm{MC}$ was $15 \mu \mathrm{M}$. Heterologously expressed human $\mathrm{Na}_{V} 1.5$ sodium channels were also affected by ibogaine. For sodium current inhibition about 25-fold higher ibogaine concentrations were needed than for hERG. Finally, experiments on isolated adult mouse cardiomyocytes showed that ibogaine also affects currents through voltage-gated ion channels in their native environment.

\section{Conclusions}

Because the ibogaine concentrations in animal and human plasma after ibogaine uptake reach low micromolar concentrations which impair the function of cardiac ion channels, the drug must be considered a potential cardiac arrhythmia risk.

\section{Acknowledgements}

Supported by the Austrian Science Fund FWF (P19352 and P23060 to K.H.).

Published: 5 September 2011

doi:10.1186/1471-2210-11-S2-A1

Cite this article as: Kovar et al.: The anti-addictive drug ibogaine

modulates voltage-gated ion channels and may trigger cardiac

arrhythmias. BMC Pharmacology 2011 11(Suppl 2):A1.

\section{Ciomed Central}

(C) 2011 Kovar et al; licensee BioMed Central Ltd. This is an open access article distributed under the terms of the Creative Commons Attribution License (http://creativecommons.org/licenses/by/2.0), which permits unrestricted use, distribution, and reproduction in any medium, provided the original work is properly cited. 